\title{
PEMBENTUKAN POLA DESAIN MOTIF KARAWO GORONTALO MENGGUNAKAN K-MEANS COLOR QUANTIZATION DAN STRUCTURED FOREST EDGE DETECTION
}

\author{
Syahrial $^{* 1}$, Rizal Lamusu \\ 1,2 Prodi. Ilmu Komputer, Fakultas Sains dan Teknologi, Universitas Muhammadiyah Gorontalo \\ Email: ${ }^{1}$ syahrial@umgo.ac.id, ${ }^{2}$ rizallamusu@umgo.ac.id \\ "Penulis Korespondensi
}

(Naskah masuk: 09 A, diterima untuk diterbitkan: 10 Juni 2021)

\begin{abstract}
Abstrak
Sulaman Karawo merupakan kerajinan tangan berupa sulaman khas dari daerah Gorontalo. Motif sulaman diterapkan secara detail berdasarkan suatu pola desain tertentu. Pola desain digambarkan pada kertas dengan berbagai panduannya. Gambar yang diterapkan pada pola memiliki resolusi sangat rendah dan harus mempertahankan bentuknya. Penelitian ini mengembangkan metode pembentukan pola desain motif Karawo dari citra digital. Proses dilakukan dengan pengolahan awal menggunakan $k$-means color quantization (KMCQ) dan deteksi tepi structured forest. Proses selanjutnya melakukan pengurangan resolusi menggunakan metode pixelation dan binarization. Luaran dari algoritma menghasilkan 3 citra berbeda dengan ukuran yang sama, yaitu: citra tepi, citra biner, dan citra berwarna. Ketiga citra tersebut selanjutnya dilakukan proses pembentukan pola desain motif Karawo dengan berbagai petunjuk pola bagi pengrajin. Hasil menunjukkan bahwa pola desain motif dapat digunakan dan dimengerti oleh para pengrajin dalam menerapkannya di sulaman Karawo. Pengujian nilai-nilai parameter dilakukan pada metode $k$-means, gaussian filter, pixelation, dan binarization. Parameterparameter tersebut yaitu: $\mathrm{k}$ pada $k$-means, kernel pada gaussian filter, lebar piksel pada pixelation, dan nilai threshold pada binarization. Pengujian menunjukkan nilai terendah tiap parameter adalah $\mathrm{k}=4$, kernel $=3 \times 3$, lebar piksel $=70$, dan threshold $=20$. Hasil memperlihatkan makin tinggi nilai-nilai tersebut maka semakin baik pola desain motif yang dihasilkan. Nilai-nilai tersebut merupakan nilai parameter terendah dalam pembentukan pola desain motif berkualitas baik berdasarkan indikator-indikator dari desainer.
\end{abstract}

Kata kunci: color quantization, k-means, structured forest, pixelation, pola desain motif, karawo

\section{FORMATION OF KARAWO GORONTALO DESIGN PATTERNS USING K-MEANS COLOR QUANTIZATION AND STRUCTURED FOREST EDGE DETECTION}

\begin{abstract}
Karawo embroidery is a unique handicraft from Gorontalo. The embroidery motif is applied in detail based on a certain design pattern. These patterns are depicted on paper with various guides. The image applied to the pattern is very low resolution and retains its shape. This study develops a method to generate a Karawo design pattern from a digital image. The process begins by using k-means color quantization (KMCQ) to reduce the number of colors and edge detection of the structured forest. The next process is to change the resolution using pixelation and binarization methods. The output algorithm produces 3 different state images of the same size, which are: edge image, binary image, and color image. These images are used in the formation of the Karawo motif design pattern. The motif contains various pattern instructions for the craftsman. The results show that it can be used and understood by the craftsmen in its application in Karawo embroidery. Testing parameter values on the k-means method, Gaussian filter, pixelation, and binarization. These parameters are k on KMCQ, the kernel on a gaussian filter, pixel width in pixelation, and threshold value in binarization. The results show that the lowest value of each parameter is $k=4$, kernel $=3 \times 3$, pixel width $=70$, and threshold $=20$. The results show that the higher these values, the better the results of the pattern design motif. Those values are the lower input to generate a good quality pattern design based on the designer's indicators.
\end{abstract}

Keywords: color quantization, $k$-means, structured forest, pixelation, motif pattern design, karawo 


\section{PENDAHULUAN}

Proses mendesain motif sampai saat ini masih dilakukan secara manual di atas kertas dan umumnya berwarna hitam dan putih saja. Desainer memakai kertas yang sudah diterapkan pola bergaris sebagai alat bantu mendesain motif Karawo. Desain motif Karawo diterapkan pada kertas pola bergaris vertikal dan horizontal. Kertas desain motif tersebut dapat dimengerti oleh pengrajin atau penyulam dalam membuat kain sulaman Karawo.

Pola desain motif Karawo sangat berperan dalam industri kerajinan sulaman khas Gorontalo. Para pengrajin menerapkan secara detail sulaman berdasarkan pola desain. Pembuatan pola desain motif melalui proses penggambaran pada kertas pola berupa garis tegak dan melintang membentuk kotak. Setiap kotak dalam kertas pola merepresentasikan satu sulaman Karawo. Desainer menggambar motif mereka berdasarkan kotak-kotak tersebut (Sudana, 2019).

Secara umum desain motif Karawo dikelompokkan dalam 4 jenis, yaitu: motif geometris, motif fauna, motif flora, dan motif alam (Hasdiana., Adiatmono and Naini, 2013). Pengembangan lebih lanjut motif-motif baru muncul berdasarkan kearifan lokal (Hasdiana et al., 2019).

Desain motif berbantu komputer saat ini hanya menggunakan pengolah gambar yang bersifat umum. Fasilitas yang ada belum mendukung untuk dicetak menjadi pola desain yang sesuai bagi penyulam. Alternatif lain dengan menggunakan pengolah citra khusus pixel art namun hasilnya tidak dapat diterapkan oleh pengrajin karena tidak terdapat penanda pola desain seperti pada kertas pola. Hal ini menyulitkan para penyulam untuk menginterpretasikannya ke dalam kain sulam Karawo.

Saat ini belum ada metode yang dapat mengubah gambar ke dalam gambar pola desain motif Karawo. Desainer yang telah memiliki desain motif masih harus melakukan desain ulang ke bentuk pola desain motif Karawo. Proses tersebut menyulitkan desainer pemula dalam mendesain motif Karawo. Hal ini menyebabkan langkanya desainer motif khusus Karawo yang terampil di daerah Gorontalo. Oleh karena itu, sangat dibutuhkan metode untuk mengubah gambar ke pola desain motif Karawo berbasis komputer.

Penelitian tentang pengolahan citra motif Karawo belum pernah dilakukan khususnya pada pembentukan citra pola desain motif. Berdasarkan pengamatan pada pola desain motif menunjukkan bahwa proses desainnya sangat mirip dengan pixel art (Kopf and Lischinski, 2011) atau citra beresolusi rendah. Proses pengubahan citra digital ke pixel art sering disebut pixelation (Gerstner et al., 2012).

Berbagai metode perubahan digital ke pixel art telah dilakukan dengan metode berbasis klasterisasi: mass constrained deterministic annealing (MCDA) (Rose, 1998), simple linear interative clustering
(SLIC) (Achanta et al., 2012), dan MCDA modifikasi dengan color palette selection (Gerstner et al., 2012, 2013). Metode lainnya dengan colordifference tolerance (Takimoto, Yoshimori and Mitsukura, 2012), superpixelator (Inglis and Craig, 2012), dan cartesian resizing ( $\mathrm{Hu}$ and Urahama, 2014). Metode yang menggunakan pembelajaran mesin: convolutional neural network (CNN) (Park et al., 2018), dan generative adversarial networks (GAN) (Serpa and Rodrigues, 2019) menghasilkan citra yang baik namun memerlukan komputasi tinggi dan data yang sangat banyak. Berdasarkan hal tersebut maka masih dibutuhkan metode pixelation yang baik digunakan untuk pembentukan pola desain motif Karawo.

Metode tersebut di atas belum praktis dan juga terlihat menjanjikan namun memerlukan komputasi tinggi untuk mendapatkan kualitas yang baik. Metode lainnya berbasis $k$-means(KM) dan variannya (Celebi et al., 2013; Albayrak, 2001; Celebi, 2009; Jiang et al., 2011; Celebi, 2011; Chen, Chen and Chien, 2008; Palus and Frackiewicz, 2013; Aziz and Kamaludin, 2016; Cheng and Wei, 2019; Palus and Frackiewicz, 2019; Thompson, Celebi and Buck, 2020) menunjukkan baik hasilnya dan dapat praktis diterapkan.

Berdasarkan penelitian-penelitian di atas $k$ means dapat digunakan untuk pengolahan awal pada proses pixelation citra. Proses pixelation masih perlu dilakukan perbaikan atau penyesuaian untuk mendapatkan hasil yang optimal.

\section{METODE PENELITIAN}

Penelitian ini menggunakan citra digital motif berwarna. Terdapat 10 citra motif dari koleksi publik (Scorpy, 2015). Citra pada gambar 1 dijadikan rujukan untuk menguji metode pembentukan pola desain motif Karawo. Citra dikumpulkan dengan format *.jpg dan *.png.

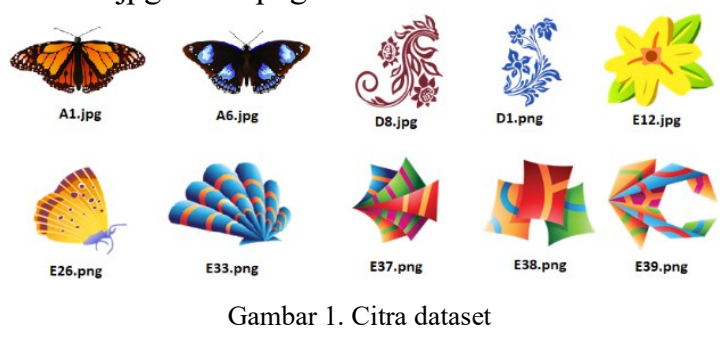

Citra diuji dengan melalui berbagai tahapan untuk membentuk citra pola desain motif Karawo. Hasil pengujian dibandingkan dengan kriteria penggambaran desain motif seperti pada gambar 2 . Tahap awal citra melalui proses pemisahan latar, selanjutnya diterapkan pengurangan jumlah warna dengan klasterisasi. Berikutnya dengan menerapkan penghalusan gambar dan mendeteksi tepi gambar pada citra. Penghalusan gambar diterapkan dengan metode berbeda untuk mendapatkan citra tepi yang bersih. 


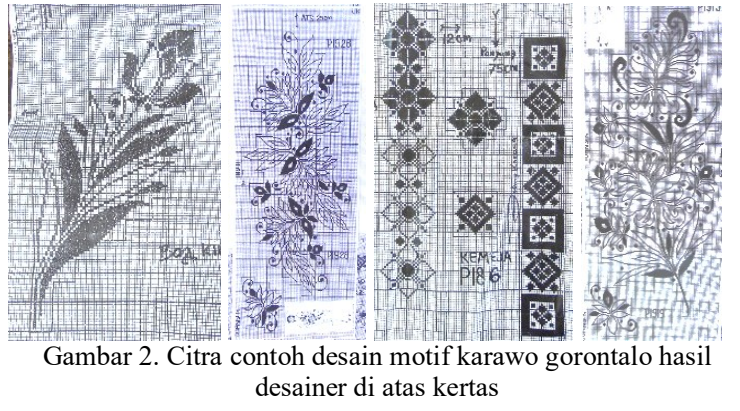

Pengurangan ukuran citra dan deteksi tepi diterapkan sehingga didapatkan citra tepi yang tipis. Tahap selanjutnya melakukan binarisasi untuk mendapatkan citra tepi tipis sampai 1 piksel. Proses tersebut menghasilkan 3 citra yaitu: citra tepi, citra biner, dan citra warna dengan ukuran sama.

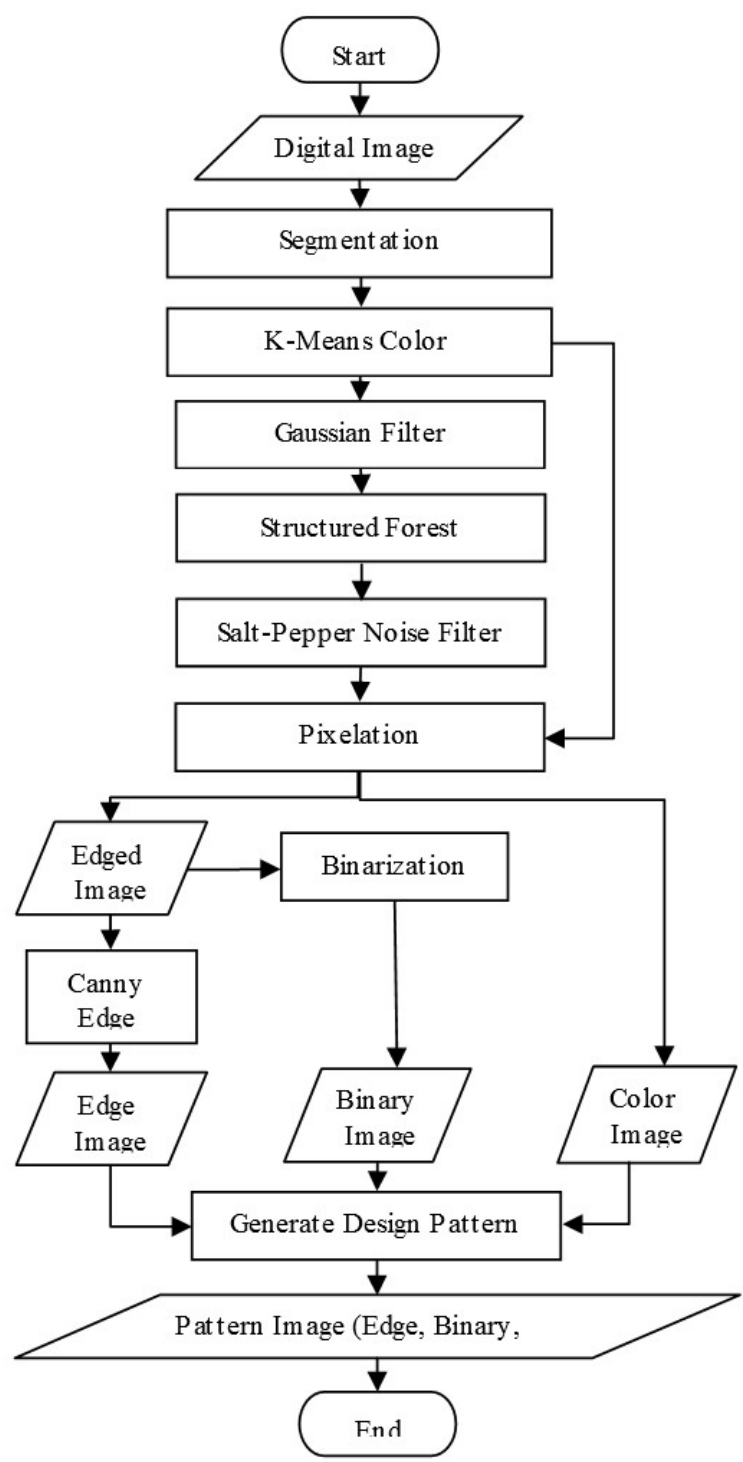

Gambar 3. Diagram alir algoritma

Proses secara detail dijelaskan pada bagianbagian selanjutnya. Pengolahan awal (preprocessing) perlu dilakukan untuk citra input karena proses pixelation harus dapat mempertahankan bentuk dan warnanya yang konsisten.

\subsection{Segmentation}

Pengolahan awal dilakukan untuk mempersiapkan dan melakukan penyesuaian citra sebelum dimasukkan ke algoritma. Tahapan ini melakukan pemisahan (segmentation) citra foreground dan background. Hal ini dilakukan untuk menghilangkan latar dan mengisolasi area citra motif.

\subsection{K-Means Color Quantization (KMCQ)}

$K$-means umumnya digunakan untuk melakukan klasterisasi data dan melakukan prediksi (Baihaqi, Pinilih and Rohmah, 2020). Pada proses pengurangan jumlah warna $k$-means diterapkan untuk membentuk citra dengan warna yang relatif seragam dan masih mempertahankan kualitasnya (Celebi et al., 2013). Hal ini sangat diperlukan saat proses pengurangan resolusi dengan pixelation.

$S S E=\sum_{k=1}^{K} \sum_{x_{i} \in S_{k}}\left\|x_{i}-c_{k}\right\|_{2}^{2}$

SSE dihitung dengan memberikan data $\mathrm{x}=$ $\left.\left\{\mathrm{x}_{1}, \mathrm{x}_{2}, \ldots, \mathrm{x}_{\mathrm{N}}\right\} \mathrm{x}_{\mathrm{N}}\right\} \in \mathbb{R}^{\mathrm{D}}$. K-means bertujuan untuk mempartisi $\mathrm{x}$ menjadi $\mathrm{K}$ dalam klaster $\mathrm{C}=$ $\left\{\mathrm{C}_{1}, \mathrm{C}_{2}, \ldots, \mathrm{C}_{\mathrm{K}}\right\} \cup_{k=1}^{K} C_{k}=x, C_{i} \cap C_{j}=\emptyset$ dalam hal ini $1 \leq \mathrm{i} \neq \mathrm{j} \leq \mathrm{K}$ dengan mencari sum of squared error (SSE) yang minimal. Pada $\|\ldots\|_{2}$ adalah jarak Euclidean dan $\mathrm{c}_{\mathrm{k}}$ adalah pusat klaster $\mathrm{C}_{\mathrm{k}}$ yang dihitung berdasarkan median dari piksel-piksel pada klaster tersebut.

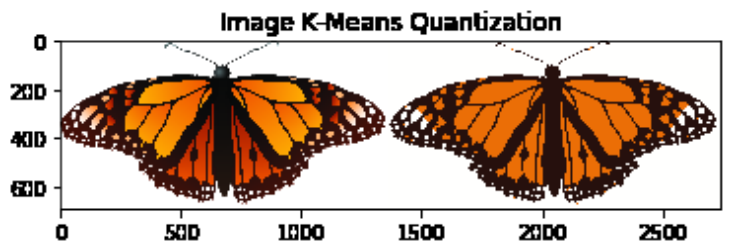

(a)

(b)

Gambar 4. Perbandingan warna citra setelah diterapkan KMCQ

(a) citra masukan, (b) citra dikurangi jumlah warna $k=3$

\subsection{Gaussian Filter}

Filter Gaussian adalah filter yang memanfaatkan fungsi Gaussian untuk pemilihan nilai pembobotan setiap anggotanya. Filter ini memiliki pusat kernel yang dapat digunakan untuk penghalusan citra. Filter ini dapat digunakan untuk meningkatkan kualitas citra (Sumijan, Purnama and Arlis, 2019).

$G(x, y)=\frac{h(x, y)}{c}=e^{\frac{x^{2}+y^{2}}{2 \sigma^{2}}}$

Persamaan 2 digunakan untuk menghitung nilai dari tiap elemen. Dalam hal ini $\sigma$ adalah deviasi standar dan $\mathrm{x}, \mathrm{y}$ merupakan posisi piksel pusat dengan bobot 1 . 


\subsection{Structured Forest Edge Detection (SFED)}

Metode ini menggunakan struktur penambalan secara lokal di tepi gambar untuk menentukan deteksi tepi yang akurat dan efisien secara komputasi (Dollar and Zitnick, 2013). Random forest dikembangkan untuk membentuk ruang struktur umum $\mathcal{Y}$ pada kasus dalam hal ini $x \in \mathcal{X}$ mewakili patch gambar dan $y \in \mathcal{Y}$ menyandikan alokasi gambar lokal yang sesuai. Proses dilakukan dengan memetakan semua label terstruktur $y \in \mathcal{Y}$ pada node tertentu menjadi satu himpunan label diskrit $\mathrm{c} \in \mathrm{C}$, di mana $\mathrm{C}=\{1, \ldots, \mathrm{k}\}$, sedemikian rupa sehingga label terstruktur serupa y ditetapkan ke label diskrit yang sama c. Diberikan C, perolehan informasi yang dihitung langsung dari $\mathrm{C}$ dapat berfungsi sebagai proxy untuk perolehan informasi melalui label terstruktur $\mathcal{Y}$.

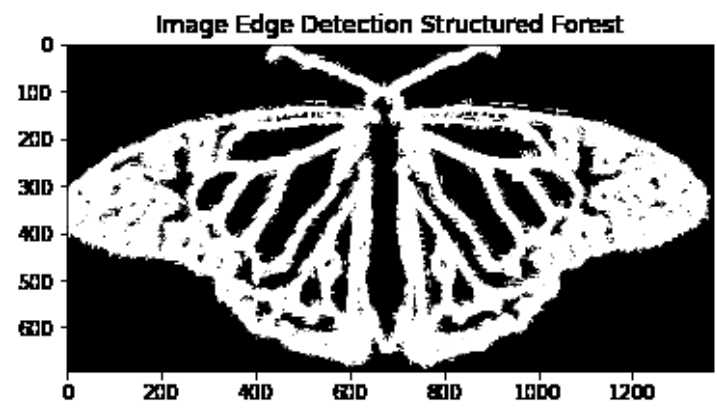

Gambar 5. Citra telah melalui deteksi tepi structured forest

\subsection{Salt-Pepper Noise Filter}

Pengurangan derau salt-pepper menggunakan median filter (Tukey, 1977). Metode ini non linier karena penapis bukan operasi konvolusi yang berfungsi menghaluskan dan mengurangi derau. Proses dilakukan dengan mengurutkan intensitas pada kumpulan piksel dan menggantinya dengan nilai tertentu. Kumpulan piksel atau window memuat jumlah piksel ganjil bergeser setiap piksel. Nilai piksel diurutkan dari kecil ke besar dan dicari mediannya. Median tersebut akan mengantikan nilai piksel pada pusat window.

\subsection{Pixelation}

Pengurangan ukuran atau resolusi citra dengan tetap mempertahankan aspek rasionya. Proses transformasi citra yang melibatkan operasi interpolasi untuk pengurangan ukuran (Distante and Distante, 2020).

$$
\begin{aligned}
& S_{x}>1 \text { dan } S_{y}>1 \rightarrow \text { Pembesaran } \\
& x^{\prime}=x \cdot S_{x} \quad 0<S_{x} \text { dan } S_{y}<1 \rightarrow \text { Pengecilan } \\
& y^{\prime}=y \cdot S_{y} \quad S_{x}=1 \text { dan } S_{y}=1 \rightarrow \text { Tak Berefek }
\end{aligned}
$$

Dalam hal ini $(x, y)$ adalah posisi piksel pada citra masukan sedangkan $\left(x^{\prime}, y^{\prime}\right)$ adalah koordinat citra luaran. $S_{x}$ dan $S_{y}$ adalah indikasinya pada tiap piksel. Jika $S_{x}$ dan $S_{y}$ nilai tidak bulat maka diterapkan interpolasi. Interpolasi diterapkan untuk menentukan nilai piksel pada koordinat luaran berdasarkan piksel pada koordinat masukan.

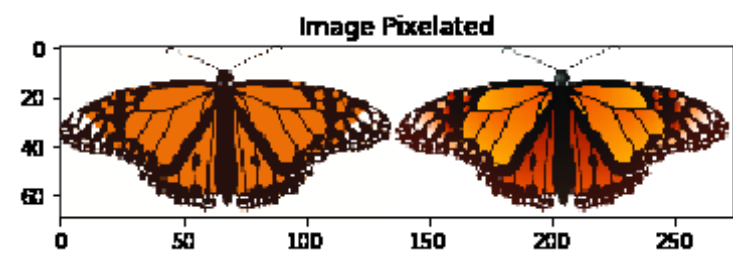

(a)

(b)

Gambar 6. Perbandingan citra telah melalui pixelation, (a) citra telah melalai kmcq, (b) citra awal

Terdapat 5 jenis interpolasi yang dapat dipakai, sebagai berikut:

a. Interpolasi tetangga terdekat, penentuan nilai keabuan berdasarkan nilai keabuan dari titik asal yang paling dekat dari hasil perhitungan transformasi.

b. Interpolasi Bilinear, nilai keabuan pada titik luaran ditentukan dari 4 titik yang bertetangga dengan bobot berdasarkan jaraknya.

c. Interpolasi Area, nilai keabuan menggunakan resampling berdasarkan hubungan area suatu piksel.

d. Intepolasi Bikubik, perhitungan nilai keabuan ditentukan dari $4 \times 4$ titik bertetangga dengan bobot berdasarkan jaraknya.

e. Interpolasi Lanczos, menghitung nilai keabuan dari $8 \times 8$ titik bertetangga dengan bobot berdasarkan jaraknya.

\subsection{Canny Edge Detection}

Deteksi tepi yang kedua diterapkan pada citra tepi luaran dari tahap 2.6 sebelumnya. Proses ini diterapkan untuk mendapatkan garis tepi yang tipis pada citra. Operator Canny memakai gaussian derivative kernel untuk menghilangkan derau dan menghasilkan deteksi tepi yang halus. Metode ini memiliki 5 langkah dalam proses deteksi tepi, sebagai berikut (Distante and Distante, 2020):

a. Noise reduction, menghilangkan derau berbasis gaussian filter kernel.

b. Gradient computation, menghitung untuk mendeteksi intensitas dan arah tepi berdasarkan gradien dari citra.

c. Non-max suppression, menyaring nilai-nilai intensitas yang tidak tinggi.

d. Hysteresis thresholding, mengubah titik tepih lemah menjadi titik kuat, jika dan hanya jika terdapat titik kuat disekitarnya.

\subsection{Binarization}

Proses ini diterapkan untuk membentuk garisgaris desain pada motif. Metode menggunakan threshold sebagai rujukan untuk perubahan ke biner.

$\operatorname{dst}(x, y)=\left\{\begin{array}{l}\text { maxvalue, } \text { if } \operatorname{src}(x, y)>\text { thresh } \\ 0\end{array}\right.$

Diberikan input citra $s r c$ dengan posisi piksel $x, y$, nilai pada piksel dari $d s t(x, y)$ tersebut akan bernilai maxvalue jika nilai piksel pada $\operatorname{src}(x, y)$ lebih besar dari nilai thresh. 


\subsection{Generate Design Pattern}

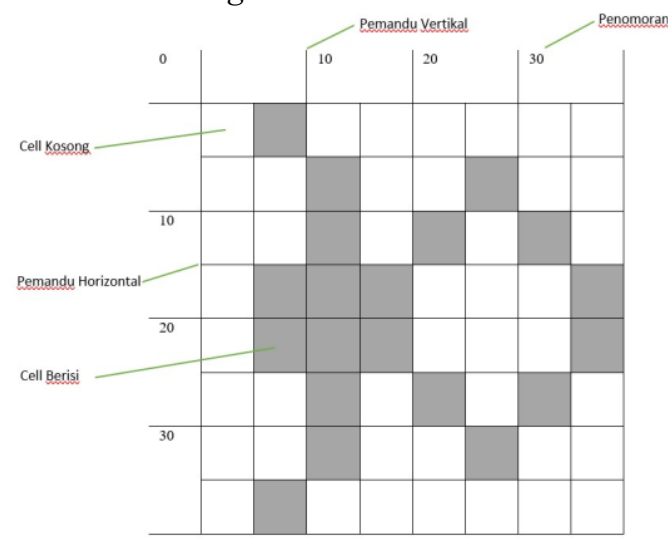

Gambar 7. Panduan pola desain motif karawo

Proses pembentukan pola desain motif Karawo dilakukan pada setiap citra luaran. Masing-masing citra dipetakan dalam ruang citra berpola. Tiap kotak dalam pola merepresentasikan 1 piksel dari citra luaran. Masukan tahapan ini berupa 3 citra dengan ukuran piksel yang sama. Pola desain yang terbentuk adalah pola desain motif, motif berwarna, dan pola desain pengirisan.

Pemetaan citra luaran ke citra pola desain Karawo diterapkan berdasarkan posisi dan nilai dari setiap pikselnya. Pola desain juga diterapkan petunjuk pengirisan dan posisi dari setiap sulaman yang akan diterapkan.

\section{HASIL DAN PEMBAHASAN}

Pengujian dilakukan untuk menemukan parameter yang menghasilkan pola desain motif yang baik. Parameter diuji pada tahap pengurangan jumlah warna $K M C Q k=1$ s.d 10 menghasilkan 100 citra. Selanjutnya setiap hasil kuantisasi warna diterapkan tahap penghalusan dengan Gaussian filter dengan kernel $=3 \times 3$ s.d $21 \times 21$ penaikan 2 menghasilkan 1000 citra. Setiap hasil dari penyaringan sebelumnya diterapkan deteksi tepi structured forest dan penyaring salt-pepper. Hasil $k$ means diterapkan pixelation dengan lebar piksel $=30$ s.d 210 penaikan 20 piksel menghasilkan 100.000 citra. Pada hasil deteksi tepi sebelumnya diterapkan pixelation dengan parameter yang sama. Hasil pixelation dari deteksi tepi ditipiskan dengan deteksi tepi canny menghasilkan 100.000 citra. Hasil yang sama diterapkan binarization dengan thresh=10 s.d 55 penaikan 5 menghasilkan 100.000 citra.

Seluruh proses menghasilkan 3 kategori citra yaitu: 100 citra yang diterapkan KMCQ, 1.000 hasil deteksi tepi SFED, 100.000 hasil dari pixelation, 100.000 citra biner, dan 100.000 citra tepi. Seluruh kategori citra tersebut dianalisis untuk mendapatkan kesimpulan parameter yang optimal. Parameter yang optimal diketahui dengan membandingkan pola desain motif karya desainer dengan luaran citra dari metode kami yang selanjutnya dibahas pada bagian 3.5. Kelompok citra biner yang dijadikan pola desain motif, citra warna sebagai panduan pemilihan warna desain, dan citra tepi sebagai panduan batas pengirisan benang pada kain. Analisis berdasarkan pengamatan citra yang dibentuk pada pola desain dengan indikator, sebagai berikut:

a. Pola dapat dibaca atau tidak terlalu kecil,

b. Garis-garis yang ada bersambung,

c. Bentuk dari motif masih utuh (topologi dipertahankan), dan

e. Garis berukuran 1 s.d 3 piksel saja.

\subsection{Pengujian Jumlah Klaster Warna Pada KMCQ}

Pengujian jumlah klaster dari $\mathrm{k}=1$ sampai dengan $\mathrm{k}=10$ dengan kenaikan 1 nilai. Pengukuran kualitas citra dengan menggunakan 3 jenis pengukuran yaitu: peak signal-to-noise ratio (PSNR), mean squared error (MSE), dan structural similarity (SSIM).

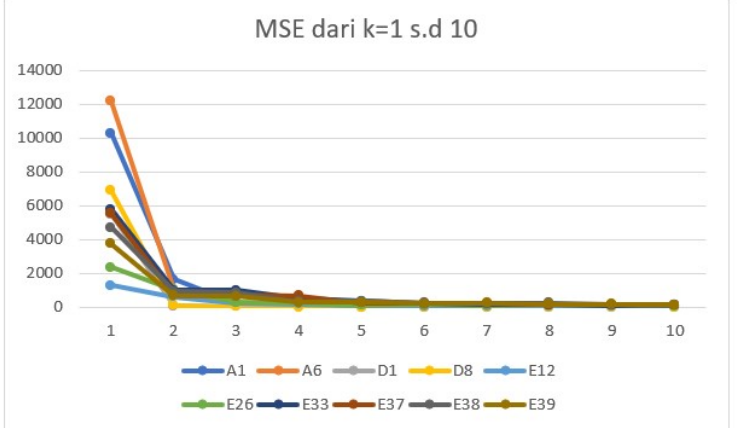

Gambar 8. Hasil MSE pada k=1 s.d 10 (kecil makin baik)

Telihat hasil pengukuran MSE makin baik jika menggunakan nilai $\mathrm{k}>=5$.

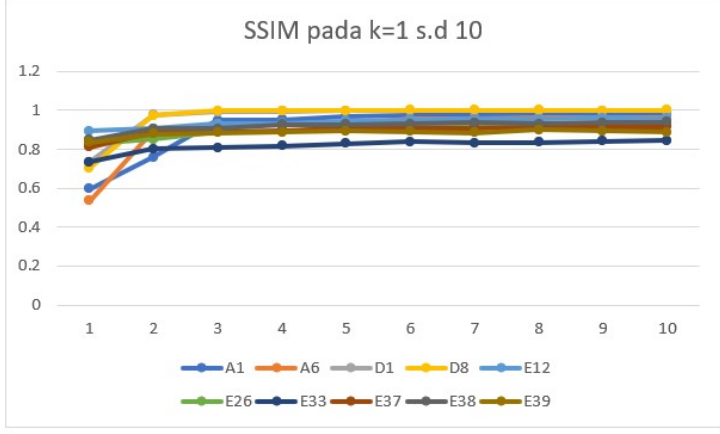

Gambar 9. Hasil SSIM pada k=1 s.d 10 (mendekati 1 makin baik)

Berdasarkan pengukuran SSIM menunjukkan $\mathrm{k}>=2$ menghasilkan citra kualitas masih baik.

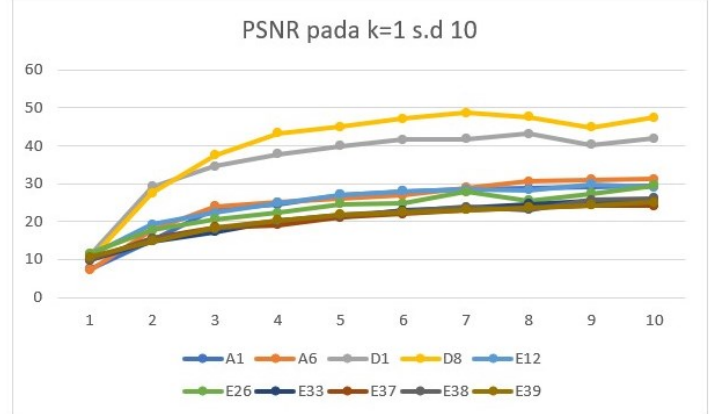

Gambar 8. Hasil PSNR pada k=1 s.d 10 (besar lebih baik) 
PSNR menunjukkan kualitas citra makin membaik setelah nilai $\mathrm{k}=2$. Pada pengamatan hasil citra pola motif menujukkan $\mathrm{k}>3$ s.d $\mathrm{k}=7$ menghasilkan citra yang sesuai dengan indikator. Nilai $\mathrm{k}$ dibawah 4 menghasilkan banyak garis terputus. Pada nilai $\mathrm{k}>7$ menghasilkan garis dengan tebal lebih dari 3 piksel dan masih ada derau.

\subsection{Pengujian Ukuran Kernel Pada Gaussian Filter}

Pengujian dilakukan untuk melihat pengaruh ukuran kernel pada pembentukan citra pola motif. Ukuran yang diuji adalah kernel=3x3 s.d $21 \times 21$ penaikan 2 nilai. Berdasarkan pengamatan citra pola yang dihasilkan, pada kernel $=3 \times 3$ s.d $9 \times 9$ pada $\mathrm{k}>=5$ s.d 9 dalam KMCQ citra motif menunjukkan hasil baik berdasarkan indikator. Pada kernel $>9 \times 9$ pada $\mathrm{k}>9$ menghasilkan pola motif banyak derau dan garis putus-putus.

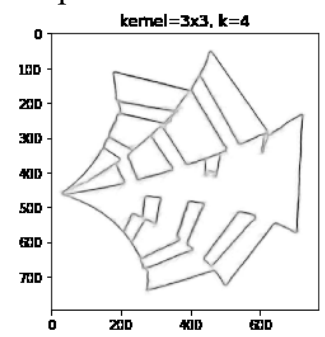

(a)

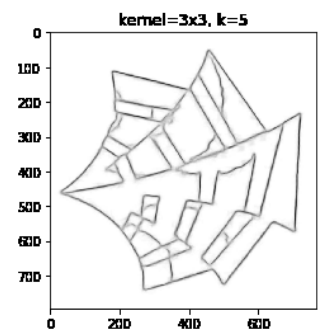

(b)
Gambar 9. Citra hasil pengujian nilai kernel 3x3, (a) motif rusak, (b) motif utuh

3.3 Pengujian Resolusi Citra Pada Proses Pixelation

Pengujian untuk mengetahui pengaruh pengurangan ukuran terhadap citra pola yang dibentuknya. Parameter yang diuji adalah lebar piksel=30 s.d 210 dengan kenaikan tiap 20 piksel. Hasil pengamatan pada citra luaran menunjukkan lebar piksel optimal pada $>=70$. Hasil pixelation dengan piksel $<70$ menghasilkan pola yang kurang dapat dibaca motifnya dan cenderung tidak utuh serta tidak proporsional.

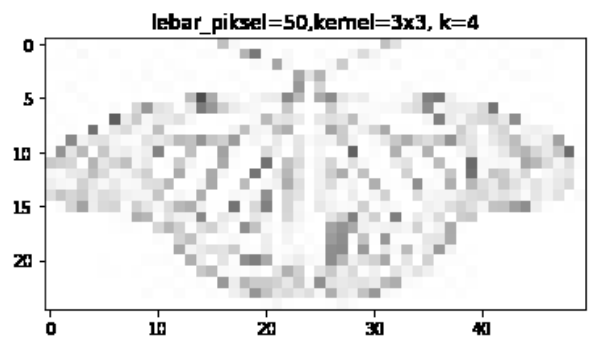

(a)

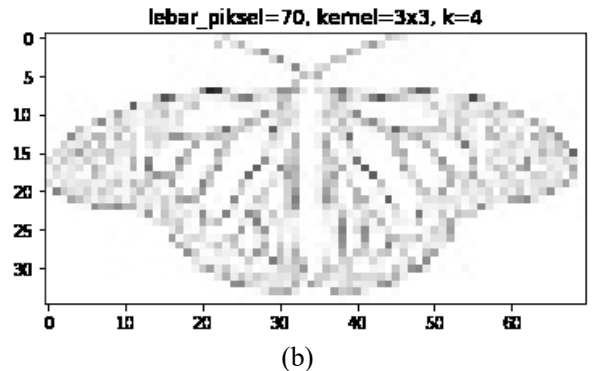

(b)

Gambar 10. Citra hasil pengujian lebar piksel pada pixelation, (a) motif rusak-garis putus, (b) motif utuh dan proporsional

\subsection{Pengujian Nilai Threshold Pada Binarization.}

Pada pengujian ini, thresh diuji pada nilai 10 s.d 55. Hal ini dilakukan untuk mengetahui pengaruh nilai threshold pada kualitas pola desain motif yang dibentuk. Tujuan lainnya adalah untuk mendapatkan rentang nilai yang optimal untuk menghasilkan motif yang baik berdasarkan indikator yang ada. Hasil pengujian menunjukkan luaran pola motif yang baik pada nilai $20<=$ thresh $<=50$. Berdasarkan indikator, didapatkan ambang batas bawah nilai parameter lainnya, yaitu: nilai piksel $=70$, kernel $=3 \times 3$, dan $\mathrm{k}=4$. Pada nilai thresh $<20$ menunjukkan hasil garis tebal dengan lebar piksel>3.

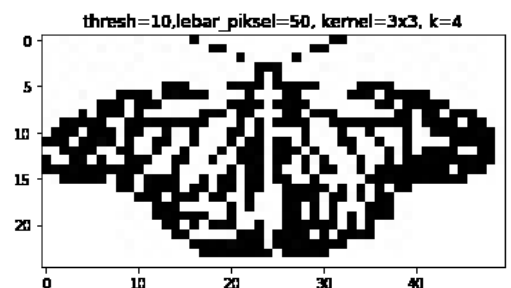

(a)

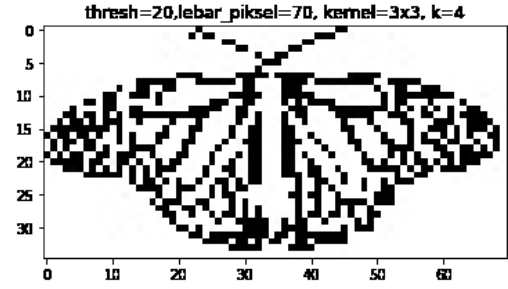

(b)

Gambar 11. Citra hasil pengujian thresh pada binarization,

(a) motif rusak-garis putus dan tebal, (b) ambang bawah parameter menghasilkan motif utuh dan garis tipis

3.5 Pembandingan Luaran dengan Hasil Penggambaran oleh Desainer

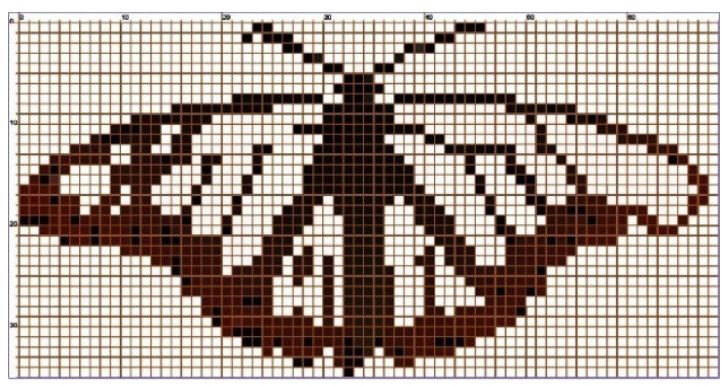

(a)

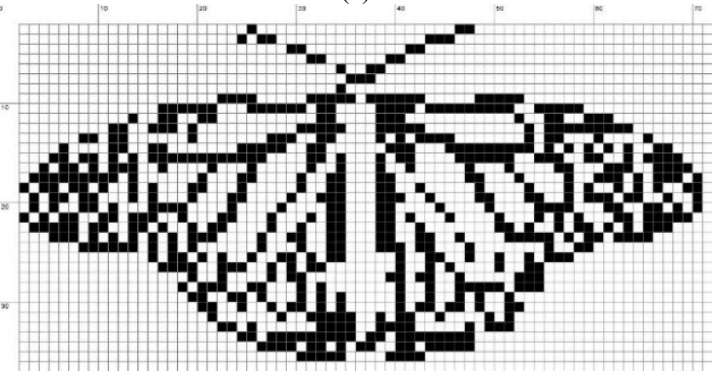

(b)

Gambar 12. Pembandingan Luaran Pola Desain Motif pada Skala Piksel yang Sama,

(a) motif hasil perancangan desainer, (b) motif luaran metode pada batas bawah setiap parameter $(\mathrm{k}=4$, kernel $=3 \times 3$, pixel $=70$, thresh $=20$ ). 
Pola desain motif luaran dari metode dengan parameter batas bawah menunjukkan sudah dapat mempertahankan bentuk dari gambar, namun masih mempertahankan banyak detail. Hal ini mengurangi nilai artistik dari gambar motif sehingga masih perlu didesain lebih lanjut. Batas bawah ini diambil berdasarkan pemenuhan indikator-indikator yang disebutkan sebelumnya.

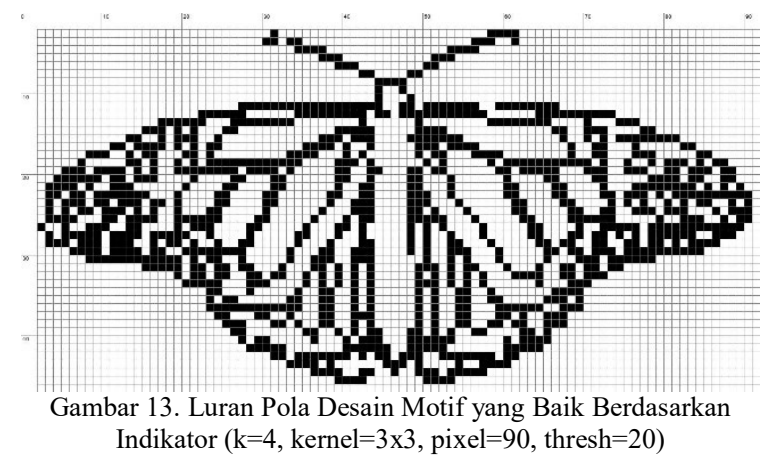

Luaran pada gambar 13 sudah menunjukkan hasil yang lebih baik berdasarkan indikator yang ada. Garis-garis tipis dan bersambung serta mempertahankan bentuk dari gambar motif. Perbaikan kecil masih harus diterapkan pada pola desain luaran.

\section{KESIMPULAN}

Penelitian ini telah dibuatkan cara mengubah citra digital menjadi citra pola desain motif Karawo sulaman khas Gorontalo. Metode yang dipakai menggunakan $k$-means untuk color quantization. Metode deteksi tepi structured forest juga dipakai untuk mengenali tepi dari citra. Luaran dari algoritma ini berupa citra pola desain yang terbentuk dari tahap akhir binarization. Selain citra pola, algorima ini juga menghasilkan citra pola tepi dan citra pola berwarna. Citra pola tepi diperlukan sebagai pemandu proses pengirisan benang untuk proses penyulaman. Citra pola berwarna dipakai sebagai pemandu dalam memberikan warna pada penyulaman Karawo pada kain.

Pengujian algoritma pada pembentukan pola motif dengan menguji nilai-nilai parameter $\mathrm{k}$ pada $k$ means, kernel pada gaussian filter, ukuran piksel pada pixelation, dan nilai threshold pada binarization. Hasil menunjukkan ambang batas bawah nilai parameter pada $\mathrm{k}=4$, kernel $=3 \times 3$, lebar piksel=70, dan threshold=20. Pada KMCQ nilai $\mathrm{k} \geq 4$ menghasilkan luaran yang baik, sedangkan kurang dari nilai tersebut cenderung membuat gambar jadi kompleks karena mempertahankan detail dari gambar. Proses blurring dengan gaussian menunjukkan kernel $\geq 3 \times 3$ menghasilkan citra tepi jelas karena mengurangi ketajaman gambar tepi dan menghilangkan detailnya. Proses pixelation dengan lebar $\geq 70$ piksel dapat menghasilkan citra yang masih mempertahankan bentuk atau topologi gambar. Pada binarization dengan nilai $20<=$ thresh $<=50$ menunjukkan luaran yang masih baik. Rentang nilai tersebut membentuk garis-garis motif yang tidak tebal. Setiap piksel dengan nilai 255 diterjemahkan menjadi titik sulaman pada pola desain motif Karawo. Berdasarkan hasil pengujian maka nilai-nilai ambang bawah tersebut sebagai panduan untuk membentuk citra pola motif Karawo yang baik dari masukan citra digital.

Berdasarkan pengamatan, luaran citra pola sudah memenuhi kriteria berdasarkan indikator yang ada. Pola desain dapat dibaca dan dapat dipakai oleh pengrajin. Pengrajin tidak mengalami kendala dalam proses pemindahan pola menjadi sulaman di atas kain karena telah ada petunjuk.

\section{DAFTAR PUSTAKA}

ACHANTA, R., SHAJI, A., SMITH, K., LUCCHI, A., FUA, P. AND SÜSSTRUNK, S., 2012. SLIC superpixels compared to state-of-theart superpixel methods. IEEE Transactions on Pattern Analysis and Machine Intelligence, 34(11), pp.2274-2281.

ALBAYRAK, S., 2001. Color Quantization by Modified K-Means Algorithm. Journal of Applied Sciences,

AZIZ, N.S. AND KAMALUDIN, A., 2016. 8 Colour Quantization of Colour Construct Code in CIELAB Colour Space Using KMeans Clustering and Hungarian Assignment. In: Advanced Computer and Communication Engineering Technology, Lecture No. [online] Switzerland: Springer International Publishing.pp.671-681. Available at: $<$ http://www.scopus.com/inward/record.url ?eid=2-s2.084955438409\&partnerID=tZOtx3yl $>$.

BAIHAQI, W.M., PINILIH, M. AND ROHMAH, M., 2020. Kombinasi K-Means dan Support Vector Machine (SVM) untuk Memprediksi Unsur SARA pada Tweet. Jurnal Teknologi Informasi dan Ilmu Komputer (JTIIK), [online] 7(3), pp.501-510. Available at: $<$ http://jtiik.ub.ac.id/index.php/jtiik/article/v iew/299>.

CELEBI, M.E., 2009. Fast color quantization using weighted sort-means clustering. Journal of the Optical Society of America A, 26(11), p.2434.

CELEBI, M.E., 2011. Improving the performance of $\mathrm{k}$-means for color quantization. Image and Vision Computing, [online] 29(4), pp.260271. Available at: $<$ http://dx.doi.org/10.1016/j.imavis.2010.10 $.002>$.

CELEBI, M.E., WEN, Q., HWANG, S. AND SCHAEFER, G., 2013. Color quantization of dermoscopy images using the K-means 
clustering algorithm. Lecture Notes in Computational Vision and Biomechanics, 6, pp.87-107.

CHEN, T.W., CHEN, Y.L. AND CHIEN, S.Y., 2008. Fast image segmentation based on Kmeans clustering with histograms in HSV color space. Proceedings of the 2008 IEEE 10th Workshop on Multimedia Signal Processing, MMSP 2008, pp.322-325.

CHENG, G. AND WEI, J., 2019. COLOR QUANTIZATION APPLICATION BASEd on K-Means in Remote Sensing Image Processing. Journal of Physics: Conference Series, 1213(4).

DISTANTE, A. AND DISTANTE, C., 2020. Handbook of Image Processing and Computer Vision. Cham, Switzerland: Springer Nature Switzerland.

DOLLAR, P. AND ZITNICK, C.L., 2013. Structured Forests for Fast Edge Detection. In: 4th IEEE International Conference on Computer Vision (ICCV '13). Sydney, Australia: IEEE Xplore.pp.1841-1848.

GERSTNER, T., DECARLO, D., ALEXA, M., FINKELSTEIN, A., GINGOLD, Y. AND NEALEN, A., 2013. Pixelated image abstraction with integrated user constraints. Computers and Graphics (Pergamon), [online] 37(5), pp.333-347. Available at: $<$ http://dx.doi.org/10.1016/j.cag.2012.12.00 $7>$.

GERSTNER, T., DECARLO, D., ALEXA, M., FINKELSTEIN, A., GINGOLD, Y. AND NEALEN, A., 2012. Pixelated image abstraction. Proceedings of the international symposium on nonphotorealistic animation and rendering (NPAR), [online] pp.29-36. Available at: $<$ http://dl.acm.org/citation.cfm?id=2330154 $>$.

HASDIANA., ADIATMONO, F.. AND NAINI, U., 2013. Peningkatan Brand Image Kerawang Melalui Penciptaan Desain Ragam Hias Kreatif Beridentitas Kultural Budaya Gorontalo Untuk Mendukung Industri Kreatif. [online] Gorontalo, Indonesia. Available at: $<$ https://repository.ung.ac.id/riset/show/2/1 027/peningkatan-brand-image-kerawangmelalui-penciptaan-desain-ragam-hiaskreatif-beridentitas-kultural-budayagorontalo-untuk-mendukung-industrikreatif.html>.

HASDIANA, NAINI, U., MOHAMAD, I. AND MALANUA, N., 2019. Engineering Design of Traditional Gorontalo Motif for Learning Karawo Embroidery. In: 1st International Conference on Education, Social Sciences and Humanities (ICESSHum 2019) Advances in Social Science, Education and Humanities Research. [online] Atlantic Press.pp.327-332. Available at: $<$ https://www.atlantispress.com/proceedings/icesshum19/125914662>.

HU, Z. AND URAHAMA, K., 2014. Cartesian resizing of line drawing pictures for pixel line arts. IEICE Transactions on Information and Systems, E97-D(4), pp.1008-1010.

INGLIS, T.C. AND CRAIG, A., 2012. Pixelating Vector Line Art. In: E. Association, ed. Proceedings of the Symposium on NonPhotorealistic Animation and Rendering. GoslarGermany: Eurographics Association.pp.21-28.

JIANG, Y., WANG, Y., JIN, L., GAO, H. AND ZHANG, K., 2011. Investigation on Color Quantization Algorithm of Color Image. In: International Conference on Electronic Commerce, Web Application, and Communication. Guangzhou, China: Springer-Verlag Berlin Heildelberg.pp.181-187.

KOPF, J. AND LISCHINSKI, D., 2011. Depixelizing Pixel Art. ACM Transactions on Graphics, 30(4), pp.1-8.

PALUS, H. AND FRACKIEWICZ, M., 2013. Colour quantisation as a preprocessing step for image segmentation. Lecture Notes in Computational Vision and Biomechanics, 8, pp.119-138.

PALUS, H. AND FRACKIEWICZ, M., 2019. Deterministic vs. random initializations for K-Means color image quantization. Proceedings - 15th International Conference on Signal Image Technology and Internet Based Systems, SISITS 2019, pp.50-55.

PARK, C., YANG, H., KWON, H. AND MIN, K., 2018. Generating Pixel Art from Game Characters with Convolutional-Neural Network. Journal of The Korean Society for Computer Game, 31(2), pp.17-24.

ROSE, K., 1998. Deterministic Annealing for Clustering, Compression, Classification , Regression, and Related Optimization Problems. In: Proceedings of the IEEE.

SCORPY, 2015. Free Vector Images. [online] allfree-download.com. Available at: $<$ https://all-free-download.com/freevectors/> [Accessed 17 Jul. 2020].

SERPA, Y.R. AND RODRIGUES, M.A.F., 2019. Towards Machine-Learning Assisted Asset Generation for Games: A Study on Pixel Art Sprite Sheets. In: 18th Brazilian 
Symposium on Games and Digital Entertainment (SBGAMES). Rio de Janeiro, Brazil: IEEE.

SUDANA, I.W., 2019. Dinamika Perkembangan Seni Karawo Gorontalo. Gelar : Jurnal Seni Budaya, 17(1), pp.31-43.

SUMIJAN, S.S., PURNAMA, A.W. AND ARLIS, S., 2019. Peningkatan Kualitas Citra CTScan dengan Penggabungan Metode Filter Gaussian dan Filter Median. Jurnal Teknologi Informasi dan Ilmu Komputer, 6(6), p.591.

TAKIMOTO, H., YOSHIMORI, S. AND MITSUKURA, Y., 2012. Method for automatic generation of pixel art based on color-difference tolerance. Kyokai Joho Imeji Zasshi/Journal of the Institute of Image Information and Television Engineers, 66(11).

THOMPSON, S., CELEBI, M.E. AND BUCK, K.H., 2020. Fast color quantization using MacQueen's k-means algorithm. Journal of Real-Time Image Processing, [online] 17(5), pp.1609-1624. Available at: $<$ https://doi.org/10.1007/s11554-01900914-6>.

TUKEY, J.W., 1977. Exploratory Data Analysis. Addison-Wesley. 
Halaman ini sengaja dikosongkan 